\title{
УДК 575:581.144.2:581.133.8:582.683.2
}

ХАБЛАК С.Г. ${ }^{1 凶}$, АБДУЛЛАЕВА Я.А. ${ }^{2}$, РЯБОВОЛ Л.О. ${ }^{3}$, РЯБОВОЛ Я.С. ${ }^{3}$

${ }^{1}$ Агропромхолдинг «Кернел», Научно-исследовательский иентр,

Украина, 17600, Черниговская обл., Варвинский район, пгт. Варва, ул. Комарова, 59,

e-mail: sergeyhab211981@gmail.com

${ }^{2}$ Агропромхолдинг «Кернел», Испытательная лаборатория,

Украина, 17600, Черниговская обл., Варвинский район, пгт. Варва, ул. Комарова, 59,

e-mail:asmina5oskar@gmail.com

${ }^{3}$ Уманский национальный университет садоводства,

Украина, 20301, г. Умань, ул. Институтская, 1, e-mail: liudmila1511@ukr.net

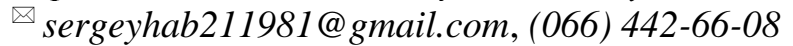

\section{ВОСПРИИМЧИВОСТЬ ГИБРИДОВ ПОДСОЛНЕЧНИКА К НОВЫМ РАСАМ ЗАРАЗИХИ}

Цель. Изучение расового состава заразихи на посевах подсолнечника в условиях северной части Степи Украины. Memodb. Оценку на устойчивость гибридов и линий-тестеров подсолнечника к заразихе проводили по модифицированной почвенной методике. Результаты. Популяция заразихи, паразитирующая на полях подсолнечника, имеет высокую степень вирулентности, которая преодолевает иммунитет лучших гибридов отечественной и иностранной селекции, устойчивых к $\mathrm{E}, \mathrm{F}$ и $\mathrm{G}$ расам данного паразита. Выводы. Появление новых очень агрессивных рас заразихи (E, F и G) свидетельствует о необходимости решения важной задачи по созданию селекционного материала, устойчивого к новым расам этого растения-паразита. Интенсивное накоплением в посевах подсолнечника паразита рас E, F и G связано с нарушением севооборотов и насыщением полей гибридами данной культуры, устойчивыми в основном к 4 (D) и 5 (Е) расам паразита.

Ключевые слова: Orobanche cumana Wallr., paca, подсолнечник, гибрид, корневая система, корневые выделения, сриголактоны.

Заразиха подсолнечниковая (Orobanche cumana Wallr.) - это паразитическое бесхлорофилльное растение, поражающее корневую систему растения-хозяина, поглощающее из неё воду, питательные вещества и выделяющее токсичные продукты обмена [1].

Исследованиями последних лет было установлено, что прорастание семян заразихи происходит благодаря стриголактонам, выделяемым в почву корнями подсолнечника, которые привлекают арбускулярные микоризные грибы (АМ-грибы), что поставляют растению некоторые питательные вещества. В то же вре- мя семена растений-паразитов также обладают способностью чувствовать стриголактоны, что является для них главным стимулом к прорастанию, прикреплению к корням растенияхозяина и высасыванию полезных веществ. Паразитизм можно считать тоже видом симбиоза, при котором один сожитель получает от него пользу, а другой - вред [2].

АМ-грибы являются самыми распространенными в почве и представляют постоянную ассоциацию с корнями более чем $90 \%$ растений. Микоризные эндогрибы проникают непосредственно в корень растения и образуют «грибницу» (мицелий), которая помогает корням укреплять иммунитет, бороться с возбудителями различных заболеваний, всасывать воду, фосфор и питательные вещества из почвы [3].

Предполагают, что возникновение симбиоза растений с грибами АМ является ключевым шагом в эволюции растений, что позволило им покинуть океаны и колонизировать землю [4]. Кроме того, считают, что повышение секреции стриголактонов при дефиците фосфора в растениях действует как сигнал в ризосфере для стимулировния развития грибов АМ [5].

Стриголактоны являются веществами «голода» растений и относятся к новому классу фитогормонов, которые выделяются корнями в почве и участвуют во многих физиологических процессах, в частности таких, как контроль развития побега, ответ на абиотические факторы, регулирование доступности питательных веществ. В последнее время на основе стриголактонов рассматриваются возможности создания новых антистрессовых препаратов, которые будут усиливать абускулярную микоризу [6].

Недавно на модельном растении Arabidopsis прослежена цепочка синтеза стри-

๑ ХАБЛАК С.Г., АБДУЛЛАЕВА Я.А., РЯБОВОЛ Л.О., РЯБОВОЛ Я.С. 
голактонов и определены ключевые генырегуляторы этого процесса. Воздействуя на них, можно снизить образование данных веществ у растений. Кроме того, методом химического скрининга отобраны пять химических соединений, которые угнетают прорастание семян заразихи. Вещества назвали котилимидами. По химической природе три из них относятся к фталимидам, два - к сукцинимидам. При обработке ими арабидопсиса в тканях снижался синтез стриголактонов, и семена заразихи, посеянные в почву рядом с такими растениями, не прорастали [7].

Используя информацию, полученную на Arabidopsis, у заразихи был идентифицирован специфичный рецептор KARRIKIN INSENSITIVE2 DIVERGENT (KAI2d), который участвует в дифференцированном распознавании корневых экссудатов подсолнечника. В геноме паразита установлено несколько генов $K A I 2 d$, что кодируют рецепторы KAI2d [8].

Гомологи гена KAI2 найдены в зеленых водорослях Харофитах (Charophyte), наземных растениях Фискомитрелле (Physcomitrella patens) и Маршаницы изменчивой (Marchantia polymorpha) [9]. Биоинформационные исследования показали, что ген KAI2 претерпел обширного размножения и изменения лигандной специфичности в геномах паразитов. Гены KAI2 в порядке Губоцветные (Lamiales) сгруппированы в три класса: консервативный $(K A I 2 c)$, промежуточный $(K A I 2 i)$ и дивергентный $(K A I 2 d)$. Гены $K A I 2 c$ и $K A I 2 i$ возникли через дублирование гена $K A I 2$ в порядке Губоцветные, а гены $K A I 2 d$ возникли путем дальнейшего дублирования и появления новых функций в заразихе [8].

В результате открытия веществ, участвующих в прорастании семян заразихи, стали обсуждаться новые стратегии защиты подсолнечника от этого растения-паразита, которые находятся на стадии разработки.

В последние годы в Украине, России наблюдается поражение заразихой гибридов подсолнечника, обладающих устойчивостью к расе Е. Потеря резистентности гибридами подсолнечника, устойчивыми к пятой (Е) расе заразихи - Згода, Од-249 и других (СГИ), Арена (Сингента), Рими, Титаник, NSH-2017 (Нови-Сад), PR63H80 (Пионер) и других, - свидетельствует, вероятно, о возникновении и интенсивном накопление новых, более вирулентных рас паразита [1].

Целью настоящей работы было определе- ние расового состава заразихи, распространенной в посевах подсолнечника в условиях северной части Степи Украины.

\section{Материалы и методы}

Объектом для исследований послужили семена заразихи. Образцы семян паразита были собраны на отдельных наиболее зараженных полях подсолнечника северной части Степи Украины. Эта популяция заразихи обладает высокой степенью вирулентности, которая преодолевает иммунитет гибридов подсолнечника, устойчивых к D расе данного паразита.

Для идентификации рас заразихи использовали гибриды и линии подсолнечника - дифференциаторы рас заразихи: Одесский-249 (СГИ-НЦСС), Згода (СГИ-НЦСС), Арена ПР (Сингента), НК Брио (Сингента), Рими (Нови Сад), Титаник (Нови Сад), С70165 (Лимагрен), ЕС Вениция (Евралис Семенс), ЕС Шерпа (Евралис Семенс), PR64A89 (Пионер), Дарий (ИРЮ), Форвард (ИРЮ), Робия КС (Коссад Семанс), ЕС Петуния (Евралис Семенс), Тунка (Лимагрейн), Голдсан (Лимагрейн), LC-1002, LC-1003 и LC-1093.

Оценку на устойчивость гибридов и линий-тестеров подсолнечника к заразихе проводили по модифицированной методике [10]. Для заражения заразихой растения подсолнечника выращивали в почвенной культуре в сосудах емкостью 10 кг, наполненных смесью почвы и песка в соотношении 3:1. Семенами заразихи инфицировали почвенную смесь из расчета 100 мг на 1 кг. При этом распределяли их равномерно в верхней трети сосуда. Семена гибридов и тест-линий подсолнечника высевали по 10 шт. в каждый сосуд. Растения культивировали при $18-25^{\circ} \mathrm{C}$. Освещенность в помещении поддерживали на уровне 16 часов в сутки в пределах 4000-7000 лк. Полив осуществляли при подсыхании верхнего слоя почвы. Через 30 дней после посева семян определяли степень поражения растений подсолнечника заразихой. Для этого растения подсолнечника выкапывали из сосудов, отмывали их корневую систему водой и подсчитывали количество клубеньков и проростков заразихи на корнях.

Математическую обработку результатов исследований проводили по Б.А. Доспехову [10], Г.Ф. Лакину [11].

\section{Результаты и обсуждение}

Дифференциация гибридов подсолнечни- 
ка по устойчивости к Orobanche cumana Wallr представлена в табл. 1. Полученные результаты показали, что растения гибридов подсолнечника по-разному поражались паразитом. Гибриды подсолнечника Одесский-249, Згода, Арена ПР, НК Брио, Рими, Титаник, С70165, ЕС Вениция, EC Шерпа, PR64A89, Дарий, Форвард, толерантные к расе Е, сильно поражались заразихой. В среднем насчитывалось от 13,3 до 19,8 клубеньков паразита на одно растение подсолнечника.

В меньшей степени заразихой поражались гибриды подсолнечника Робия КС, ЕС Петуния, Тунка, Голдсан, резистентные к расам F и G. B среднем на одно растение подсолнечника приходилось 2,9-8,8 клубеньков паразита. Гибридов подсолнечника, обладающих полным иммунитетом к заразихе, не было выявлено.

Подобные результаты получены и при поражении заразихой линий-дифференциаторов подсолнечника (табл. 2). По результатам иссле- дований выявлено разную реакцию линийдифференциаторов подсолнечника на поражение паразитом. Линии-тестеры LC-1002 и LC1003 , устойчивые соответственно к расам $\mathrm{D}$ и $\mathrm{E}$, в значительной степени поражались заразихой. Так, растения линии-дифференциатора LC-1002 при заражении семенами паразита поражались на $100 \%$, а растения линии-дифференциатора LC-1003 - на 95\%, при чем в среднем на одно растение тест-линии LC-1002 приходилось 16,9 шт. клубеньков заразихи, тогда как на одно растение тест-линии LC-1003 - только 10,6 клубеньков паразита.

В то же время линия-тестер LC-1093, peзистентная к расе $\mathrm{F}$, поражалась в меньшей степени заразихой. Процент пораженных растений линии LC-1093 семенами паразита соответственно составлял $85 \%$. При этом в среднем насчитывалось 5,5 шт. клубеньков заразихи на одно растение линии-дифференциатора LC1093.

Таблица 1.Степень поражения гибридов подсолнечника заразихой

\begin{tabular}{|c|c|c|c|c|}
\hline $\begin{array}{c}\text { Гибриды подсолнечника, } \\
\text { собственник, } \\
\text { год регистрации }\end{array}$ & $\begin{array}{l}\text { Устойчи- } \\
\text { вость } \\
\text { к расе зара- } \\
\text { зихи }\end{array}$ & $\begin{array}{c}\text { Число протести- } \\
\text { рованных } \\
\text { растений, шт. }\end{array}$ & $\begin{array}{c}\% \\
\text { поражен- } \\
\text { ных расте- } \\
\text { ний }\end{array}$ & $\begin{array}{c}\text { Количество } \\
\text { клубеньков заразихи } \\
\text { на } 1 \text { пораженное } \\
\text { растение } \\
\text { (среднее значение) }\end{array}$ \\
\hline $\begin{array}{l}\text { Одесский-249 (СГИ-НЦСС), } \\
1998\end{array}$ & A-E & 20 & 100 & $15,0 \pm 0,3$ \\
\hline Згода (СГИ-НЦСС), 1996 & A-E & 20 & 100 & $13,3 \pm 0,4$ \\
\hline Арена ПР (Сингента), 2003 & A-E & 20 & 100 & $18,8 \pm 0,2$ \\
\hline НК Брио (Сингента), 2004 & A-E & 20 & 100 & $16,6 \pm 0,5$ \\
\hline Рими (Нови Сад), 2005 & A-E & 20 & 100 & $18,2 \pm 0,3$ \\
\hline Титаник (Нови Сад), 2004 & $\mathrm{~A}-\mathrm{E}$ & 20 & 100 & $15,9 \pm 0,4$ \\
\hline С70165 (Лимагрен), 2005 & A-E & 20 & 100 & $14,4 \pm 0,3$ \\
\hline $\begin{array}{l}\text { ЕС Вениция (Евралис Се- } \\
\text { менс), } 2010\end{array}$ & A-E & 20 & 100 & $16,1 \pm 0,2$ \\
\hline $\begin{array}{l}\text { ЕС Шерпа (Евралис Се- } \\
\text { менс), } 2011\end{array}$ & A-E & 20 & 100 & $17,2 \pm 0,3$ \\
\hline PR64A89 (Пионер), 2008 & A-E & 20 & 100 & $19,8 \pm 0,4$ \\
\hline Дарий (ИРЮ), 2005 & A-E & 20 & 100 & $17,6 \pm 0,6$ \\
\hline Форвард (ИРЮ), 2008 & A-E & 20 & 100 & $16,9 \pm 0,3$ \\
\hline $\begin{array}{l}\text { Робия КС (Коссад Семанс), } \\
2010\end{array}$ & A-F & 20 & 95 & $8,8 \pm 0,3$ \\
\hline $\begin{array}{l}\text { ЕС Петуния (Евралис Се- } \\
\text { менс), } 2010\end{array}$ & A-F & 20 & 95 & $7,3 \pm 0,1$ \\
\hline Тунка (Лимагрейн), 2010 & $A-G$ & 20 & 85 & $3,1 \pm 0,3$ \\
\hline Голдсан (Лимагрейн), 2010 & A-G & 20 & 80 & $2,9 \pm 0,2$ \\
\hline \multicolumn{4}{|l|}{$\mathrm{HCP}_{05}$} & 1,2 \\
\hline
\end{tabular}


Таблица 2. Степень поражения линий-дифференциаторов подсолнечника заразихой

\begin{tabular}{|c|c|c|c|c|}
\hline $\begin{array}{c}\text { Тест-линия } \\
\text { подсол- } \\
\text { нечника }\end{array}$ & $\begin{array}{c}\text { Устойчивость тест- } \\
\text { линии к расе зарази- } \\
\text { хи }\end{array}$ & $\begin{array}{c}\text { Число протести- } \\
\text { рованных } \\
\text { растений, шт. }\end{array}$ & $\begin{array}{c}\% \\
\text { пораженных } \\
\text { растений }\end{array}$ & $\begin{array}{c}\text { Количество } \\
\text { клубеньков заразихи на } \\
1 \text { пораженное } \\
\text { растение (среднее значе- } \\
\text { ние) }\end{array}$ \\
\hline LC-1002 & A-D & 20 & 100 & $16,9 \pm 0,4$ \\
\hline LC-1003 & A-E & 20 & 95 & $10,6 \pm 0,2$ \\
\hline $\mathrm{LC}_{1093}$ & $\mathrm{~A}-\mathrm{F}$ & 20 & 85 & $5,5 \pm 0,1$ \\
\hline $\mathrm{HCP}_{05}$ & \multicolumn{3}{|r|}{} & 1,4 \\
\hline
\end{tabular}

Селекция подсолнечника на устойчивость к заразихе ведется постоянно на протяжении почти столетия, так как в ходе сопряженной эволюции с подсолнечником у этого растенияпаразита периодически возникают новые вирулентные расы, преодолевающие иммунитет существующих сортов [13].

Вначале 60-х годов прошлого столетия появилась новая раса заразихи С, которую назвали «молдавской» популяцией, что привело впоследствии к эпифитотийной обстановке в стране. К ней все сорта отечественной селекции того времени оказались восприимчивыми. Однако в течение десяти последующих лет успешная селекция, направленная на выведение новых сортов подсолнечника на устойчивость к этой pace, позволила решить данную проблему [14].

В конце 80-х годов прошлого столетия был проанализирован расовый состав популяций заразихи на посевных площадях подсолнечника в СССР. Был сделан вывод о преобладании повсеместно расы С (так был назван в СССР молдавский биотип). Последние исследования румынских и испанских ученых свидетельствуют о том, что в 2000-2007 годах возникли новые, более вирулентные - Е (5-ая), F (6-ая), G (7-ая) и Н (8-ая) расы заразихи. В настоящее время эти расы заразихи распространены в Испании, Румынии, Турции, Болгарии и ряде других стран [15].
Примерно до конца 90-х годов проблем с заразихой на подсолнечнике в Украине и России не возникало. Однако в последние годы из разных мест Ставропольского и Краснодарского краев, а также Ростовской области стали поступать сведения о сильной засоренности посевов подсолнечника заразихой (Антонова, 2011) [1].

Данные наших исследований показывают, что популяция заразихи в начале XXI века, которая паразитирует на посевах подсолнечника северной части Степи Украины, имеет высокую степень вирулентности, которая преодолевает иммунитет лучших гибридов отечественной и иностранной селекции, устойчивых к $\mathrm{E}, \mathrm{F}$ и $\mathrm{G}$ рас данного паразита. Появление новых очень агрессивных рас заразихи (Е, F и G) свидетельствует о необходимости решения важной задачи по созданию селекционного материала, устойчивого к новым расам этого растения-паразита.

Как правило, такую высокую вирулентность заразихи из популяции в северной части Степи Украины можно объяснить нарушением севооборотов и насыщением полей гибридами данной культуры, устойчивых в основном до 4 (D) и 5 (Е) рас паразита.

\section{Выводы}

В посевах подсолнечника северной части Степи Украины паразитирует заразиха E, F и G pac.

\section{Литература}

1. Бурлов В.В. Ефективність генів Or у забезпеченні стійкості соняшнику до нових рас вовчка (Orobanche cumana Wallr.). Селекиія і насінництво. 2010. № 98. С. 28-37.

2. Yoneyama K., Xie X., Kisugi T., Nomura T., Sekimoto H., Yokota T. et al. Characterization of strigolactones exuded by Asteraceae plants. Plant Growth Regul. 2011. Vol. 65. P. 495-504.

3. Reinhardt D. Programming good relations: development of the arbuscular mycorrhizal symbiosis. Curr. Opin. Plant Biol. 2007. Vol. 10. P. 98-105.

4. Bonfante P., Genre A. Plants and arbuscular mycorrhizal fungi: an evolutionary-developmental perspective. Trends Plant. 2008. Vol. 13. P. 492-498.

5. Bouwmeester H.J., Roux C., Lopez-Raez J.A., Bécard G. Rhizosphere communication of plants, parasitic plants and AM fungi. Trends Plant Sci. 2007. Vol. 12. P. 224-230.

6. Albrecht H., Yoder J.I., Phillips D.A. Flavonoids promote haustoria formation in the root parasite Triphysaria versicolor. Plant Physiol. 1999. Vol. 119. P. 585-591. 
7. Brewer P.B., Koltai H., Beveridge C.A. Diverse roles of strigolactones in plant development. Mol. Plant. 2013. Vol. 6. P. 1828.

8. Conn C.E., Bythell-Douglas R., Neumann D., Yoshida S., Whittington B., Westwood J.H., et al. Convergent evolution of strigolactone perception enabled host detection in parasitic plants. Science. 2015. Vol. 349. P. 540-543.

9. Waters M.T., Scaffidi A., Moulin S.L., Sun Y.K., Flematti G.R., Smith S.M. A Selaginella moellendorffii ortholog of KARRIKIN INSENSITIVE2 functions in Arabidopsis development but cannot mediate responses to karrikins or strigolactones. Plant Cell. 2015. Vol. 27. P. 1925-1944.

10. Кукин В.Ф. Метод оценки подсолнечника на устойчивость к заразихе. Защита растений от вредителей и болезней. 1960. № 7. С. 39.

11. Доспехов Б.А. Методика полевого опыта (с основами статистической обработки результатов исследований). М.: Агропромиздат, $1985.351 \mathrm{c}$.

12. Лакин Г.Ф. Биометрия. М.: Высш. шк., 1990. 352 с.

13. Бейлин И.Г. Цветковые полупаразиты и паразиты. М.: Наука, 1968. 118 с.

14. Антонова Т.С. Развитие гаусторий заразихи подсолнечной в корнях иммунных и поражаемых форм подсолнечника. Ботанич. журн. 1978. № 7. С. 1025-1029.

15. Kaya Y., Evci Y., Pekcan V., Gucer T. Determining new broomrape infested areas, resistant lines and hybrids in Trakya region of Turke. Helia. 2004. № 27. P. 211-218.

\section{References}

1. Burlov V.V. Efficiency of org genes in providing sustainability of sunflower to new rabies (Orobanche cumana Wallr.). Selection and seed production. 2010. Vol. 98. P. 28-37.

2. Yoneyama K., Xie X., Kisugi T., Nomura T., Sekimoto H., Yokota T. et al. Characterization of strigolactones exuded by Asteraceae plants. Plant Growth Regul. 2011. Vol. 65. P. 495-504.

3. Reinhardt D. Programming good relations: development of the arbuscular mycorrhizal symbiosis. Curr. Opin. Plant Biol. 2007. Vol. 10. P. 98-105.

4. Bonfante P., Genre A. Plants and arbuscular mycorrhizal fungi: an evolutionary-developmental perspective. Trends Plant. 2008. Vol. 13. P. 492-498.

5. Bouwmeester H.J., Roux C., Lopez-Raez J.A., Bécard G. Rhizosphere communication of plants, parasitic plants and AM fungi. Trends Plant Sci. 2007. Vol. 12. P. 224-230.

6. Albrecht H., Yoder J.I., Phillips D.A. Flavonoids promote haustoria formation in the root parasite Triphysaria versicolor. Plant Physiol. 1999. Vol. 119. P. 585-591.

7. Brewer P.B., Koltai H., Beveridge C.A. Diverse roles of strigolactones in plant development. Mol. Plant. 2013. Vol. 6. P. 1828.

8. Conn C.E., Bythell-Douglas R., Neumann D., Yoshida S., Whittington B., Westwood J.H., et al. Convergent evolution of strigolactone perception enabled host detection in parasitic plants. Science. 2015. Vol. 349. P. 540-543.

9. Waters M.T., Scaffidi A., Moulin S.L., Sun Y.K., Flematti G.R., Smith S.M. A Selaginella moellendorffii ortholog of KARRIKIN INSENSITIVE2 functions in Arabidopsis development but cannot mediate responses to karrikins or strigolactones. Plant Cell. 2015. Vol. 27. P. 1925-1944.

10. Kukin V.F. A method for assessing sunflower resistance to broomrape. Protection of plants from pests and diseases. 1960. № 7. P. 39.

11. Dospekhov B.A. Methodology of field experience (with the basics of statistical processing of research results). M.: Agropromizdat, $1985.351 \mathrm{p}$.

12. Lakin G.F. Biometriya. M.: Vysh. shk., 1990. 352 p.

13. Beilin I.G. Flower half parasites and parasites. M.: Science, 1968. 118 p.

14. Antonova T.S. The development of haustoria broomrape in the sunflower in the roots of immune and affected forms of sunflower. Botanich. journal. 1978. № 7. P. 1025-1029.

15. Kaya Y., Evci Y., Pekcan V., Gucer T. Determining new broomrape infested areas, resistant lines and hybrids in Trakya region of Turke. Helia. 2004. № 27. P. 211-218.

HABLAK S.G. ${ }^{1}$, ABDULLAEVA Y.A. ${ }^{2}$, RYABOVOL L.O. ${ }^{3}$, RYABOVOL Y.S. ${ }^{3}$

${ }^{1}$ Agropromholding Kernel, Research and Development Center,

Ukraine, 17600, Varva, e-mail: sergeyhab211981@gmail.com

${ }^{2}$ Agrompromholding "Kernel", Testing laboratory,

Ukraine, 17600,Varva, e-mail: asmina5oskar@gmail.com

${ }^{3}$ Umanian National University of Horticulture,

Ukraine,20301,Uman,e-mail: liudmila1511@ukr.net

\section{SUSCEPTIBILITY OF SIBERIAN HYBRIDS NEW RACES OF ZARAZHI}

Aim. A study of the racial composition of broomrape on sunflower crops in the northern part of the Steppe of Ukraine. Methods. Assessment of the resistance of hybrids and sunflower test lines to broomrape was carried out by a modified soil method. Results. The broomrape parasitizing on the fields of sunflower has a high 
degree of virulence, which overcomes the immunity of the best hybrids of domestic and foreign breeding, resistant to the E, F and G races of this parasite. Conclusions. The emergence of new very aggressive broomrape races (E, F and $\mathrm{G}$ ) indicates the important need to solve the problem of creating breeding material resistant to new races of this parasitic plant. Intensive with the accumulation of parasite races $\mathrm{E}, \mathrm{F}$ and $\mathrm{G}$ in the sunflower crops is associated with the disruption of crop rotations and the saturation of fields with hybrids of this culture, resistant mainly to 4 (D) and 5 (E) races of the parasite.

Keywords: Orobanche cumana Wallr., race, sunflower, hybrid, root system, root allocation, srigolactones.

ХАБЛАКУ С.Г. ${ }^{1}$, АБДУЛЛАСВА Я.А. ${ }^{2}$, РЯБОВОЛ Л.О. ${ }^{3}$, РЯБОВОЛ Я.С. ${ }^{3}$

${ }^{1}$ Агропромхолдинг «Кернел», Науково-дослідний иентр, Україна, 17600, с. Варва, e-mail: sergeyhab211981@gmail.com

${ }^{2}$ Агропромхолдинг «Кернел», Випробувальна лабораторія, Україна, 17600, с. Варва, е-mail: asmina5oskar@gmail.com

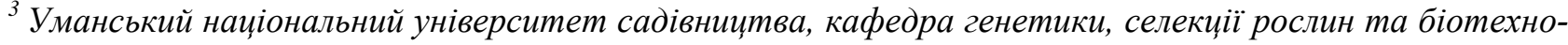
логіï,

Україна, 20301, м. Умань, е-mail: liudmila1511@ukr.net

\section{ЧУТЛИВІСТЬ ГІБРИДІВ СОНЯШНИКУ ДО НОВИХ РАС ВОВЧКА}

Мema. Вивчення расового складу вовчка на посівах соняшнику в умовах північної частини Степу України. Методи. Оцінку на стійкість гібридів і ліній-тестерів соняшнику до вовчка проводили за модифікованою грунтовою методикою. Результати. Популяція вовчка, яка паразитує на полях соняшнику, має високу ступінь вірулентності, яка долає імунітет кращих гібридів вітчизняної та іноземної селекції, стійких до E, F i G рас цього паразита. Висновки. Поява нових дуже агресивних рас вовчка (Е, F i G) свідчить про важливу необхідність вирішення завдання зі створення селекційного матеріалу, стійкого до нових рас цієї рослини-паразита. Інтенсивне накопиченням у посівах соняшнику паразита рас E, F i G пов'язано з порушенням сівозмін і насиченням полів гібридами цієї культури, стійкими в основному до 4 (D) і 5 (E) рас паразита.

Ключові слова: Orobanche cumana Wallr., paca, соняшник, гібрид, коренева система, кореневі виділення, сріголактони. 